\title{
SOVIETINIO LAIKOTARPIO ARCHITEKTŪROS KONKURSŲ RAIDOS APŽVALGA
}

\author{
Darius Linartas \\ Architektūros teorijos ir pagrindų katedra, Vilniaus Gedimino technikos universitetas, \\ Pylimo g. 26/Traku g. 1, LT-0113 Vilnius, Lietuva. \\ El.paštas darlinas@gmail.com \\ Itteikta 20081222
}

\begin{abstract}
Santrauka. Straipsnyje aptariami svarbesni sovietinio periodo (1945-1990 m.) architektūros konkursai Lietuvoje. Peržvelgiami ankstyvojo ir vèlyvojo socializmo urbanistinių, pastatų, monumentų konkursų ypatumai. Aprašomai epochai būdinga „mirusių“ projektų, konkursų nerezultatyvumo ir neskaidrumo problematika. Remiantis esmingesniais konkrečių kūrybinių varžybų pavyzdžiais bandoma atsekti konkursų raidos dėsningumus ịvairiais laikotarpio etapais, rasti santykị su bendra laikmečio geopolitine situacija, aptarti pokyčius, palyginti su kitų istorinių periodų konkursais, nustatyti galimą reikšmę to meto Lietuvos architektūros vystymuisi ir architektų tobulejjimui.
\end{abstract}

Reikšminiai žodžiai: architektūros konkursas, sovietiniai metai, „miręs“ projektas, igyvendinimas, autorystė.

\section{Ivadas}

Sovietinè okupacija ir Antrasis pasaulinis karas nutraukè jau igavusią pagreitị kūrybinių konkursų tradiciją Lietuvoje. Nepriklausomoje tarpukario Lietuvoje architektūros konkursai buvo itin populiarūs (per trumpą dviejų dešimtmečių laikotarpi (1918-1940 m.) jų surengta apie 40 (Kančienė 1996), o per 45 sovietinès okupacijos metus konkursų vidurkis nepasiekè net prieškarinio lygio (Žickis 1996). Dar prastesni pokario rodikliai būtų, jeigu lygintume šiuos du Lietuvos architektūros periodus pagal igyvendintų konkursinių projektų kiekį. Tarpukario Lietuvos architektūros formavimuisi ir architektų tobulëjimui konkursai turejjo akivaizdžios teigiamos ịtakos (Kančienè 1996), o konkursų reikšmę sovietiniu periodu ịvertinti sudètingiau. Turime pripažinti, kad dauguma reikšmingesnių to meto architektūros objektų suprojektuoti ne konkurso būdu. Tačiau negausus pačiu konkursų kiekis, menkas jų rezultatyvumas, rašytinès informacijos stygius dar neleidžia teigti apie menką jų itaką to meto architektų kūrybai ir architektūros meno vystymuisi. Tai greičiau tik vienas iš sovietinès epochos ypatumų, kuris rodo gilesnès nei apžvalginio straipsnio apimties analizès būtinybę.

\section{Ankstyvieji konkursai}

Aktyviai sovietinių metų architektūros procesuose dalyvavę lietuvių architektai teigia, kad Lietuvoje buvo tęsiamos prieškario mokyklos tradicijos, nors pripažįstama, kad Lietuva dèl karo ir pokario neteko beveik viso kūrybinio potencialo (Nekrošius 2007). Trūkstant kadrų iš Rusijos (daugiausia iš tuometinio Leningrado) i Lietuvą buvo siunčiami architektai. Todèl pirmaisiais pokario metais, taip kaip ir Sovietų Sajungoje, Lietuvoje vyravo „atvežtine““ retrospektyvinè stalininè architektūra (Mačiulis 2002). Esant tokiai situacijai vidinès projektuotojų konkurencijos, o kartu ir natūralios konkursų būtinybès nebuvo. Tie negausūs konkursai, kurie vis tik ịvyko, buvo direktyviškai inicijuoti vietinès ar sajunginès valdžios.

Ko gero, pirmasis sovietinis konkursas ịvko prabėgus pusmečiui po Antrojo pasaulinio karo pabaigos. Tuo metu TSRS statybos reikalų komitetas surengè keletą uždarų architektūrinių konkursų, kurių tikslas buvo pateikti siūlymus nuo karo veiksmų ypač nukentèjusių respublikų sostinių centrinių dalių generaliniams projektams. Vienas buvo skirtas Lukiškių aikštès Vilniuje ir aplinkinių teritorijų sutvarkymo urbanistiniam 

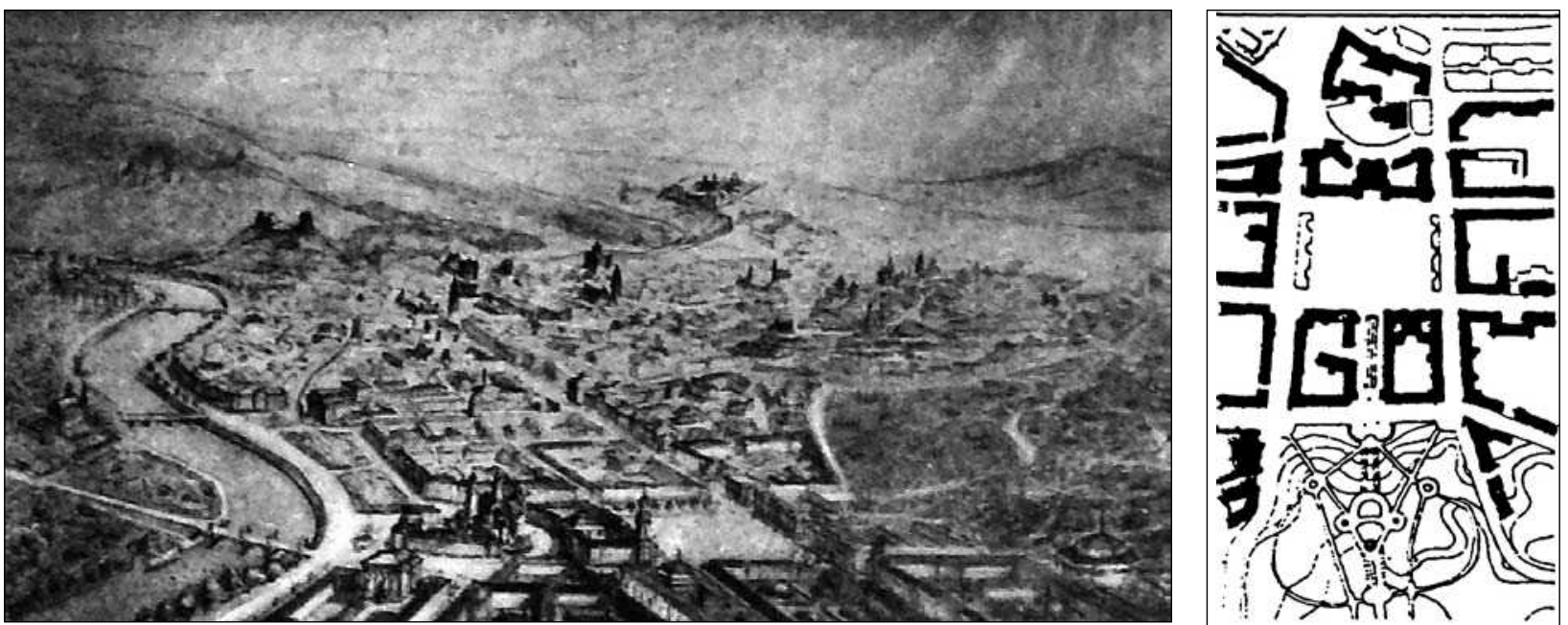

1 pav. Lukiškių aikštès konkursinis projektas (archit. V. Mikučianis, 1945 m.)

Fig. 1. Competitive design of Lukiškès Square, 1945. Architect V. Mikučianis

sprendimui rasti. Tam tikslui buvo numatyta parengti šešis užsakomuosius projektus. Po du projektus turejo pateikti Maskvos, Leningrado ir Lietuvos architektai. Maskvai atstovavo architektų A. Velikanovo, N. Šelomovo bei I. Sobolevo kolektyvai, leningradiečiams S. A. Gegello ir A. Baručevas, J. Rubančikas, o Lietuvai K. Šešelgis, V. Zubovas ir V. Mikučianis. Konkurso dalyviams buvo keliamas uždavinys išspręsti pagrindinès miesto aikštès ir vyriausybinių pastatų komplekso lokalizavimo Lukiškių aikštès teritorijoje uždavinį, ịtraukiant ị projektuojamą teritoriją Tauro kalną ir aplinkinius jo kvartalus (Mikučianis 1997). Remdamasi konkursui pateiktais darbais, žiuri rekomendavo toliau plètoti Vilniaus vyriausiojo architekto V. Mikučianio projektą (1 pav.).

Kartu patarta atsižvelgti ị planavimo pasiūlymus, kuriuos savo projekte pateike architektai V. Zubovas ir K. Šešelgis. Kaip vèliau rašè vienas iš konkurso dalyvių, „<...> gyvenimas lèmè, kad, veikiant aukščiausios respublikinès ir maskvietiškos valdžios diktatui, buvo igyvendinta tik nedidele minèto projekto idejų dalis $<$... " (Mikučianis 1997).

Nepaisant to Lukiškių aikštè ir toliau liko populiariu architektūros konkursų objektu. K. Šešelgis vien sovietiniais metais aprašo dar šešias projektavimo šioje teritorijoje iniciatyvas. Net keturios iš jų daugiau ar mažiau panašèjo ị konkursus. Nei vienas iš konkursinių darbų sumanymų nebuvo realizuotas. Lietuvos miestuose nèra kito tokio urbanistinio komplekso (aikštès, kvartalų grupès, visuomeninių pastatų komplekso ir pan.), kuriam statyti ir tvarkyti būtu parengta tiek daug projektų (Šešelgis 1997).
Šeštojo dešimtmečio viduryje Sovietų Sajungoje atsisakoma puošybiškos architektūros pompastiškumo, radikaliai keičiasi ir idejinè estetinè architektūros programa. Tam įtakos turejjo asmenybès kulto pabaiga bei demokratijos fikcijos užuomazgos. Architektūros stilistika ima artèti prie pasaulinès architektūros estetikos. Lietuvos architektai vieni pirmųjų Sovietų Sąjungoje pradejo dirbti pagal tuo metu ideologiškai naują kūrybinį metodą, paprasčiau dar ịvardinamą sovietiniu modernizmu (Nekrošius 2007). Čia savo žodị tarè jau naujoji architektų karta - Kauno politechnikos instituto ir Vilniaus dailess instituto architektūros fakultetų absolventai N. Bučiūtè, G. Baravykas, A. Nasvytis, V. E. Čekanauskas, V. Bredikis ir kt. (Mačiulis 2002).

Šị kūrybinį lūžì, ko gero, geriausiai atspindi uždaras Vilniaus operos ir baleto teatro konkursas, kuris ịvyko $1956 \mathrm{~m}$. Vertinimo komisijai svarstyti buvo pateikta bene dešimt projektų. Pirmoji vieta suteikta architekto A. Spelskio parengtam projektui. Antrą̧ą vietą pelnė A. Lukošaičio darbas, o trečiają - Miturič. Tačiau kai po ịvairių šio konkurso rezultatų svarstymų, ekspertavimų ir naujų idèjų iškèlimo Respublikos vyriausybẻ dar kartą išnagrinejo teatro projektavimo ir statybos klausimą, buvo galutinai nutarta pakeisti sklypą Mindaugo gatvejje bei projektuoti naują teatrą buvusio dujų fabriko teritorijoje (Mikučianis 1997). Šiame etape konkurso principu rengti projektus buvo užsakyta tik dviem architektams - pirmojo konkurso laimètojui A. Spelskiui ir dar jaunai architektei N. Bučiūtei. Kaip tik tuo metu prasidejjęs sudètingas esminių architektūros koncepcijų keitimosi procesas nulèmè, kad dviejų architektų 


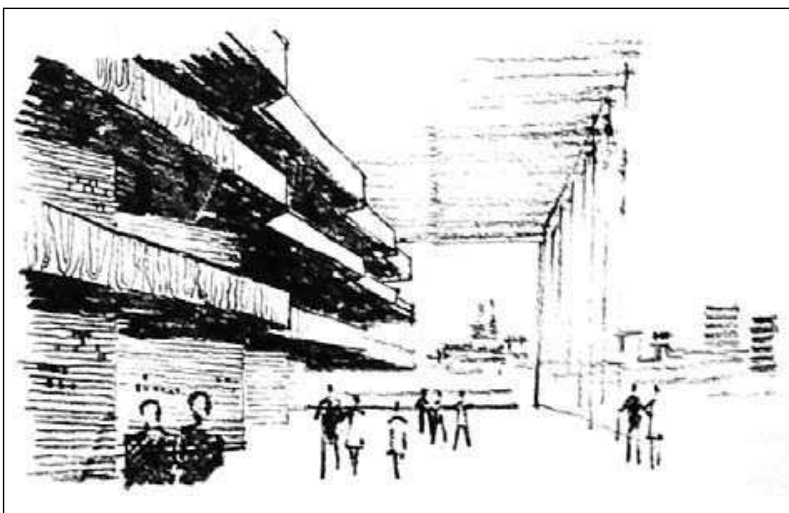

a

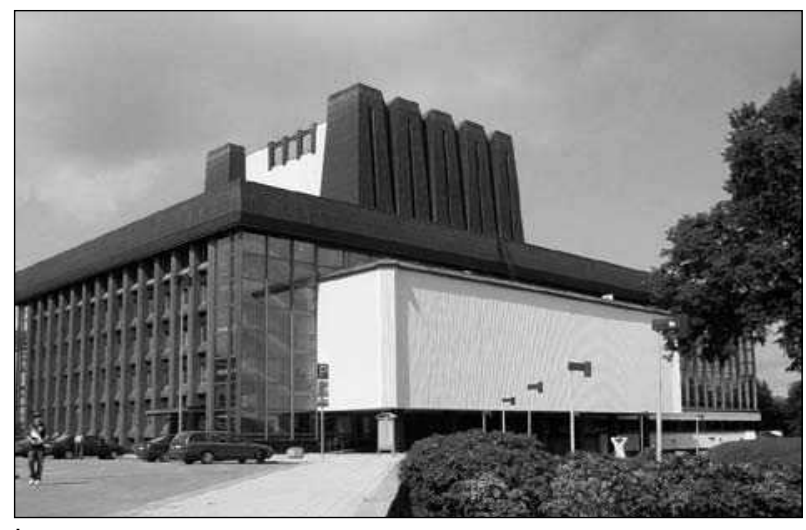

b

2 pav. Vilniaus operos ir baleto teatras - interjero projekto eskizas (a) ir vaizdas igyvendinus projektą (b) (archit. N. Bučiūtè) Fig. 2. Vilnius Opera and Ballet Theatre. Sketch of interior design (a) and view after realization (b). Architect N. Bučiūtè

kūrybines varžybas $1958 \mathrm{~m}$. laimèjo tada labai novatoriškas ir originalus atrodęs Nijolès Bučiūtès projektas (2 pav.).

Jai ir buvo patikètas tolesnis teatro kūrimas, kuris po daugelio metų $1974 \mathrm{~m}$., kiek pakitęs, palyginti su konkursiniu projektu, egzistuoja ir yra plačiai žinomas kūrinys ir dabar (Mikučianis 1997).

\section{Urbanistiniai ir pastatų projektų konkursai}

Aktyviai sovietinių metų architektūros procesuose dalyvavę lietuvių architektai teigia, kad Lietuvoje buvo tęsiamos prieškario mokyklos tradicijos ir taip pat jaučiama Vakarų bei Vidurio Europos patirties įtaka pokario Lietuvos urbanistikai (Devinduonis 1998) ir architektūrai (Buivydas 2006). Vis dèlto neretai pabrèžiama, kad užsienio architektūros tendencijas to meto projektuotojai suvokdavo fragmentiškai ir formaliai. Neišvengiamai to meto projektus (kaip bendros sovietų architektūros politikos dalis) veikè ir TSRS direktyvos. Šie procesai atsispindejo ir projektų konkursuose. Deja, apie tiesioginę urbanistinių ir pastatų konkursų reikšmę sovietinių metų architektūrai teigti problemiška vien dèl to, kad jie vyko retai ir dar rečiau buvo igyvendinami. Jei atliktume reikšmingesnių tuo periodu ivvkusių konkursų atranką pagal laimèjusių projektų igyvendinimo kriterijų, tai gautume dar trumpesni sąrašą:

- Vilniaus operos ir baleto teatras. Konkursas 1958 m. I premija - N. Bučiūte. Projektas realizuotas $1974 \mathrm{~m}$. (Riaubienè 1999).

- Vilniaus m. centro detaliojo planavimo uždaras sajunginis konkursas 1964 m. tarp Vilniaus, Leningrado, Minsko ir Rygos projektavimo institutų grupių (Cibas 1964). I premija - neskirta. II premija - A. Nasvytis,
V. Brėdikis ir V. E. Čekanauskas, A. A. Jakučiūnas (3 pav.). Realizuota dalis urbanistinių sprendinių (Mačiulis 2002).

- Revoliucijos muziejus Vilniuje (dabar Nacionalinè galerija). Konkursas 1966 m. I premija - G. Baravykas, P. Adomaitis, V. Vielius, R. Pranaitis, S. Šarapovas. Realizuotas 1971-1980 m. (Buivydas 2000).

- Studentų miestelis Vilniuje. Konkursas 1965 m. I premija - J. Jurgelionis. Realizuotas 1970-1985 m. (Mačiulis 2002). LTSR Aukščiausios Tarybos pastatas Vilniuje, Gedimino pr. Konkursas $1970 \mathrm{~m}$.

I premija - A. Nasvytis, V. Nasvytis, R. Stasenas. Realizuotas 1976 m. (Petrulis 2007).

Iš igyvendintų statinių pavadinimų matyti, kad tai reprezentaciniai ar ideologiškai svarbūs valstybiniai objektai. Tokio objekto statusas kažkuria prasme paaiškina ir "netipiškai sklandžią“ sovietiniams laikams Revoliucijos muziejaus Vilniuje atsiradimo istoriją. 1966 m. ịvykusị atvirą kūrybinị konkursą laimèjo jauni architektai G. Baravykas, P. Adomaitis, V. Vielius, R. Pranaitis (4 pav.). Tie patys autoriai ir igyvendino projektą. Kalbèdamas apie šią aplinkybę R. Buivydas savo monografijoje pastebi: „Galbūt būtent dèl to ši kūrinị vèl ir vèl norisi charakterizuoti kaip mūsų architektūros bene iškiliausią, intelektualiai kondensuoto sudètingumo ir kartu paprastumo simbiozès kūrinị $<\ldots . .>$ " (Buivydas 2000).

Dèsninga, kad architektūra ir architektūros konkursai, kaip ir viskas sovietiniais metais, pakluso planinès ekonomikos, generalinio reguliavimo ir kontrolès principams. Dažnas kūrybiškesnis, tačiau ideologiškai "nenaudingas" objektas patekdavo $i \mathfrak{i}$ "mirusių“ projektų kategoriją, t. y. taip ir nebūdavo igyvendintas (6 pav.). 

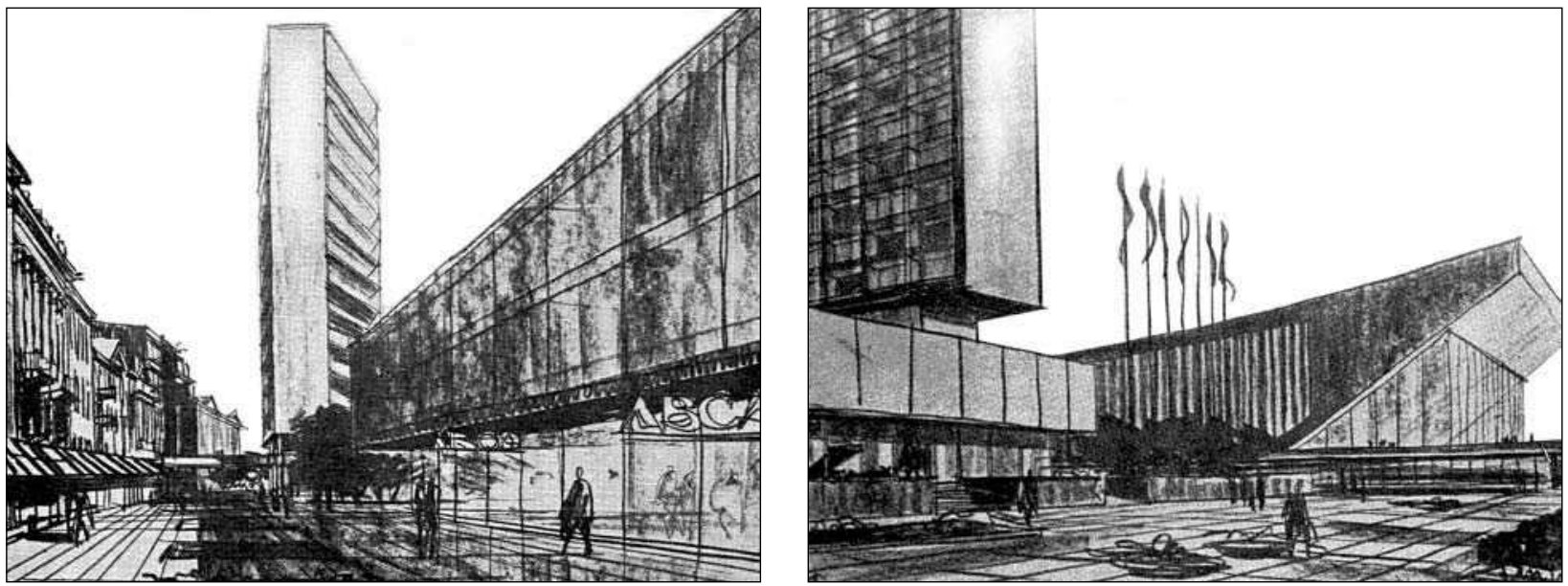

3 pav. Vilniaus m. centro rekonstrukcijos konkursinis projektas (archit.: A. Nasvytis, V. Bredikis, V. E. Čekanauskas, A. A. Jakučiūnas, 1964 m.)

Fig. 3. Competitive design of Vilnius city center reconstruction, 1964. Architects A. Nasvytis, V. Brèdikis and V. E. Čekanauskas, A. A. Jakučiūnas

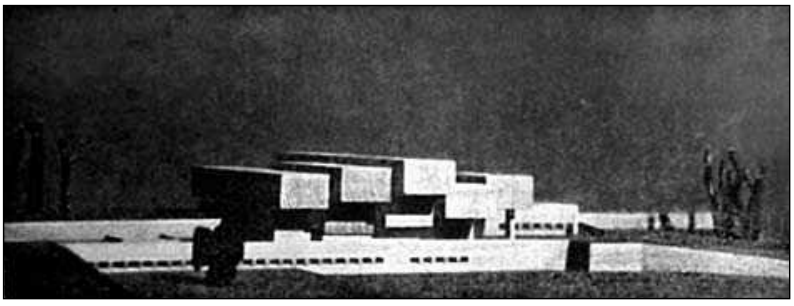

4 pav. Revoliucijos muziejus Vilniuje (dabar Nacionalinè galerija). Konkursinis maketas (archit.: G. Baravykas, P. Adomaitis, V. Vielius, R. Pranaitis) Fig. 4. Revolution Museum in Vilnius (present National Gallery). Competitive model. Architects G. Baravykas, P. Adomaitis, V. Vielius, R. Pranaitis

Konkursiniai projektai šią kategoriją papildydavo ypač dažnai.

1978 m. lapkritị izyko atviras konkursas, skirtas parengti Kauno autobusų stoties plano ir užstatymo projektą. Konkurso nugalètojais tapo architektai A. Alekna, G. Telksnys, L. Vaitys (5 pav.). Daug atgarsio architektūrinèje visuomenejje sukèlęs jų darbas ịvardijamas kaip sèkmingas tuo metu į Lietuvos architektūrą pro „geležinę uždangą " prasiskverbusio postmodernizmo pavyzdys (Vyšniūnas 1997). Deja, autorių siūlytos idejos taip ir nebuvo realizuotos. Savo straipsnyje A. Vyšniūnas ironiškai pažymi: „Vis dèlto, man atrodo, gerai, kad Kauno autobusų stoties projektas buvo neįgyvendintas. Aštuntojo dešimtmečio pabaigoje statybos kultūros lygis buvo nevertas tokio projekto <... >“.

Iliustratyvus pavyzdys - nuolatinių konkursų dalyvių ir prizininkų architektų S. Šarkino ir L. Merkino darbų sąrašas - vien sovietiniais metais per 12 kūrybos metų (1977-1989 m.) dalyvauta 8 konkursuose, iš jų laimètos 3 pirmosios premijos, gauti 4 garbingi pažymèjimai. Dèl ịvairiausių priežasčių nei vieno laimèto konkurso projektas (4 pav.), net ir parengus visą projektinę dokumentaciją, nebuvo realizuotas (Vaitys 2007).

Taigi galima teigti, kad sovietinès Lietuvos konkursų istorijoje „mirusių“ projektų klodas yra gerokai gausesnis ir vertingesnis nei igyvendintu, o dauguma (net ir reikšmingų) to laikotarpio urbanistinių ir architektūrinių sprendinių buvo realizuoti ne konkurso būdu.

\section{Monumentų konkursai}

Kiek dinamiškiau ir laisviau nei urbanistikos ir architektūros sovietiniais metais vystèsi monumentų konkursai. Pažymètina, kad būtent ši konkursų, kuriuose dalyvavo ir architektai, rūšis pirmoji tapo vieša ir ženklino giluminius laikmečio meninès kūrybos poslinkius.

1958 m. įvyko paminklo Pirčiupio aukoms konkursas (I premija - architektai V. E. Čekanauskas, V. Brèdikis); 1961 m. - paminklo fašizmo aukoms Paneriuose konkursas (realizuotas tik 1984 m., architektas J. Makariūnas); 1965 m. paminklo žuvusiems pogrindininkams Kaune konkursas (I premija - architektai G. Baravykas, V. Vielius, skulptorius S. Šarapovas; realizuotas 19751979 m.) (7 pav.). 1968-1970 m. net keturiais etapais organizuojamas IX forto memorialinio komplekso Kaune konkursas (I premija - architektai G. Baravykas, V. Vielius, A. Ambraziūnas, skulptorius S. Šarapovas; realizuotas 1975-1983 m.) (Buivydas 2000). 

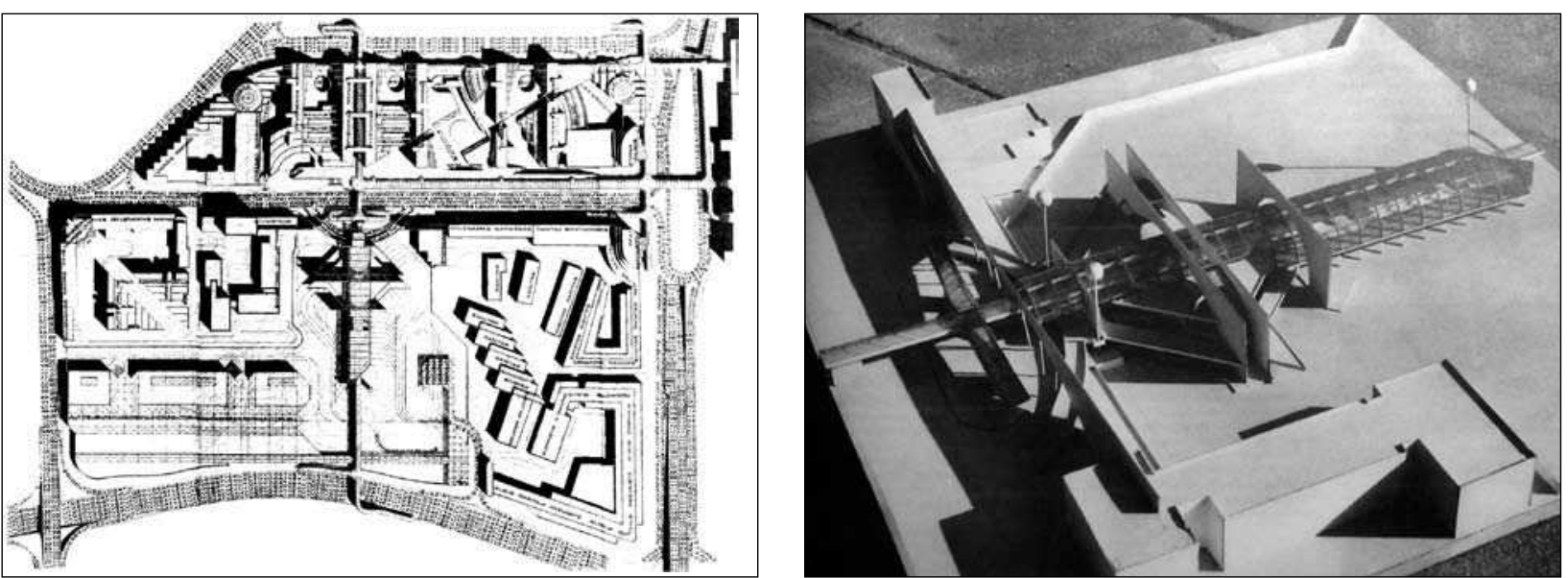

5 pav. Kauno autobusu stoties konkursinis projektas (archit.: A. Alekna, G. Telksnys, L. Vaitys, 1978 m.) Fig. 5. Competitive project of Bus Station in Kaunas, 1978. Architects A. Alekna, G. Telksnys, L. Vaitys
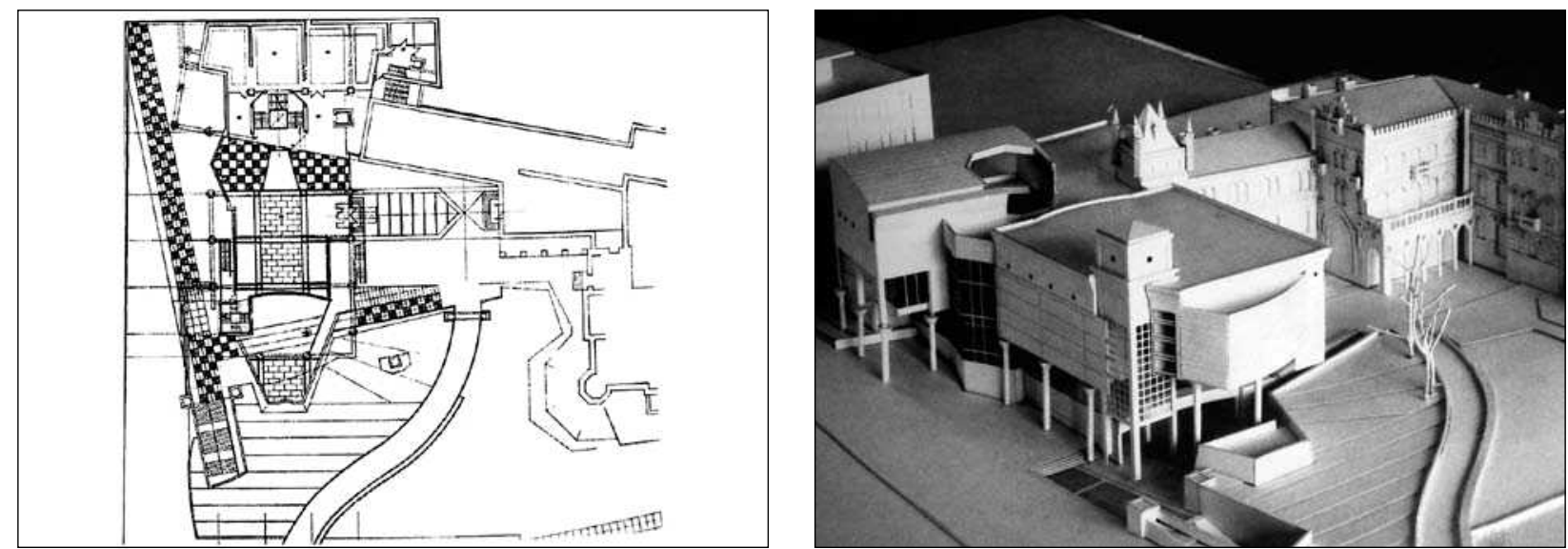

6 pav. „Miręs" projektas - Kino lektoriumo rūmai (archit. L. Merkinas ir S. Šarkinas). Planas ir maketas

Fig. 6. "Dead" project of Cinema Lecturing House in Vilnius. Architects L. Merkinas and S. Šarkinas. Plan and model

Šie monumentų konkursai žymëjo perëjimą nuo stalininiu laikotarpiu valstybiškai proteguoto socrealizmo estetinių normų prie abstrakčių modernizmo estetikos kanonų.

Pavyzdžiui, stambiausio to meto monumento IX forto memorialinio ansamblio ( 8 pav.) galutinis sumanymas formavosi keliais etapais, o svarbiausia vykusių pakitimų priežastis buvo valdžios surengti net keturi konkurso etapai, per kuriuos buvo mèginama rasti geriausią variantą. Konkursas daugeliui amžininku j̇siminè kaip nepaprastai ịdomios kūrybiniu idèju varžybos ir, deja, kaip atgrasi užkulisinès veiklos apoteozè. Ir per IX forto konkursų turus vyko labai nepaprasta kova tarp tiesmukai „tikroviškos“ ir stereotipiškai ideologizuotos monumento sampratos, idiegtos Lietuvoje nuo pokario, iš vienos pusès, ir naujos, labiau apibendrintos meninès kalbos, iš kitos. Naujos, moder- nios kūrybos šalininkams kaip tik ir priklausė memorialo autoriai (Buivydas 2000). Projekto realizacija tapo svarbiu to meto meninès kūrybos įvykiu.

Didesnis, palyginti su architektūros objektų konkursais, sovietinių monumentų igyvendinimo procentas kažkuria prasme parodo epochai būdingą propagandinị ir ideologini prioritetų pobūdị, kai buvo realizuojami reikalaujantys mažiau kapitalinių i̇dejimų, bet politiškai veiksmingesni projektai. Kitaip sakant, ideologinis projekto sumanymas užtikrindavo sklandesni jo finansavimą ir ịgyvendinimą.

\section{Kūrybinių konkursų vieta sovietinès santvarkos kontekste}

Abejonių nekelia politinès santvarkos integralumas su kitais visuomeneje vykstančiais procesais (taip pat 


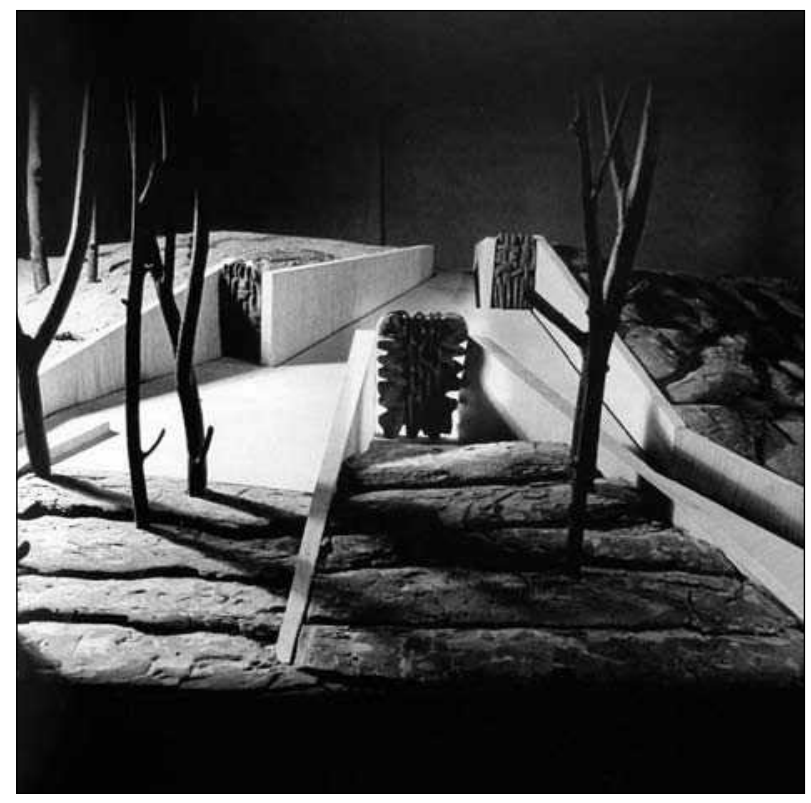

7 pav. Paminklo žuvusiems pogrindininkams Kaune modelis (archit:. G. Baravykas, V. Vielius, A. Ambraziūnas, skulptorius S. Šarapovas)

Fig. 7. Competitive model of Monument for Killed Undergrounders in Kaunas. Architects G. Baravykas, V. Vielius, A. Ambraziūnas, sculptor S. Šarapovas

ir architektūriniais). Projekto konkursas - tai demokratiniai architektūrinès idejos rinkimai. Dėsninga, kad kiekybiniai ir kokybiniai poslinkiai pasaulineje projektų konkursų istorijoje sutapdavo su demokratiniais pakilimais visuomeninëje, pvz.: senovès Graikija, Renesansas (De Haan, Haagsma 1988). Todèl, remdamiesi architektūros konkursų praktika, galime spręsti apie tam tikrų periodų ir vietų visuomeninių ir politinių procesų „sveikatą“, o kartu ir apie prielaidas architektūros pažangai.

Fiktyvi sovietine demokratija, siekdama atitikti deklaruojamų vertybių kriterijus, privalejo organizuoti ne tik politinius, bet ir meninès kūrybos rinkimus konkursus. Tačiau statybų masto neatitinkantis mažas organizuotų konkursų ir ịgyvendintų konkursinių projektų kiekis rodo, kad bendruoju atveju architektūros kokybè nebuvo prioritetinè. Išimtį sudare tik politiniu ir ideologiniu požiūriu svarbūs objektai. Tą patvirtina ịgyvendintų konkursinių objektų paskirtis - Revoliucijos muziejus, Aukščiausios Tarybos rūmai, sovietiniai monumentai. Tačiau Kauno autobuso stotis ar Kino lektoriumo rūmų Vilniuje konkursų darbai papilde „mirusių" projektų kategoriją.

Tai, kad konkursas yra puiki priemonè išvengti asmeninės atsakomybės už būsimojo objekto kokybę, suprato dar senovès Graikijoje, kai $448 \mathrm{~m}$. pr. Kr. Atenų miesto taryba organizavo viešą konkursą Persų kare sugriautam akropoliui atstatyti (De Haan, Haagsma 1988). Sovietų Sajungoje, kur vyravo nuolatinè atsiskaitomybe, tai galèjo būti vienu iš konkursų organizavimo motyvų. Veiklos ataskaita aukštesnei valdžiai galejo tapti ne tik realizuotas objektas, bet paties konkurso faktas. Bent jau toks parodomasis veiklos scenarijus galètų iš dalies paaiškinti daugybès nerezultatyvių Lukiškių aikštès konkursų istoriją, kurioje $1952 \mathrm{~m}$. buvo apsiribota tik dangų sutvarkymu ir paminklo Leninui pastatymu. Taigi vengiant sudètingesnių bendrųjų miesto uždavinių sprendimo buvo ịvykdyta propagandiškai efektyviausia dalis - „<...> suformuota gigantiška ašis nuo Tauro kalno, Profsąjungų rūmų, i̇ aikštę, kurios centre stovèjo absoliučios tarybinès diktatūros „steigèjas“ $<\ldots$.. "(Grunskis 2007).

Remdamiesi Lukiškių aikštès pavyzdžiu galime daryti prielaidą, kad konkursams būdavo patikimi sudètingi, neskubūs ar daug léšų reikalaujantys uždaviniai. Tokiais atvejais konkursų organizatorių motyvacija galèjo būti daugiau parodomojo, ideologinio pobūdžio, siekiant atsiskaitomybès prieš aukštesnę valdžią, nei susijusi su greitesne ir efektyvesne objekto realizacija.

Sovietinių konkursų organizatoriai nejaute jokios atsakomybès ir ịsipareigojimų konkurso dalyviams - nei autorystès, nei projekto realizacijos klausimu. Buvo taupomos statybinès medžiagos ir darbininkų darbo valandos, tačiau nebuvo vertinamas intelektualinis ir kūrybinis darbas. Konkursai buvo skelbiami neturint aiškios projektavimo užduoties, esant nekonkrečioms ar dviprasmiškoms sąlygoms. Ši aplinkybè atsiskleidè pirmaisiais nepriklausomybès metais, kai netobulas sovietinių metų konkursų sistemos mechanizmas buvo bandytas pritaikyti besiformuojančios laisvos rinkos sąlygomis (Čaikauskas 1999). Iprastinių sovietinių konkursų organizatorių Lietuvos TSR Ministrų Tarybos valstybinio statybos reikalų komiteto ir LTSR architektų sąungos sudarytose konkurso sąlygose neretai būdavo keliami pernelyg nerealūs ar sunkiai igyvendinami uždaviniai. A. Vyšniūnas, apibūdindamas Kauno autobusų stoties konkurso sąlygose pateiktų pertvarkymų mastą, rašè: „, _..> jų rankos nesąmoningai tiesési prie galingų buldozerių vairalazdžių <...>“. Taigi konkurso sąlygų netobulumas ir nerealūs užsibrežti uždaviniai taip pat galëjo būti viena iš sovietinès konkursinès sistemos neefektyvumo priežasčių.

Okupuotoje Lietuvoje konkursai negalejjo plètotis kaip laisva konkurencija, o buvo tik administracinès tvarkos dalis (Žickis 1996). Projektavimo institutai buvo griežtai pasidalinę veiklos sritimis ir jas monopolizavę. Komunalinio ūkio projektavimo institutas 


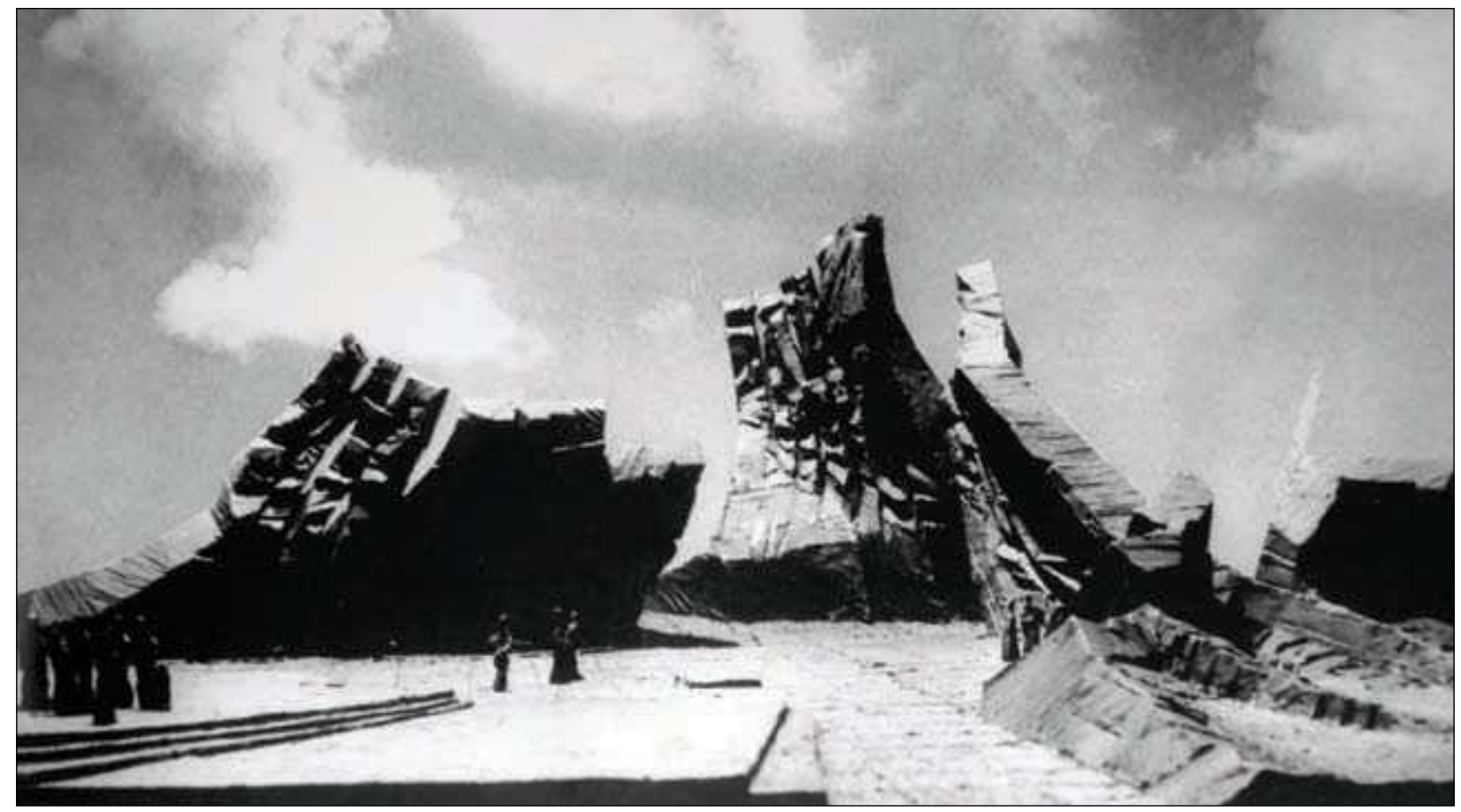

8 pav. IX forto memorialo eskizinis modelis (archit.: G. Baravykas, V. Vielius, A. Ambraziūnas, skulpt. S. Šarapovas) Fig. 8. Model of Memorial IX Fortas. Architects G. Baravykas, V. Vielius, A. Ambraziūnas, sculptor S. Šarapovas

(„Komprojektas“) specializavosi rekonstrukcijų srityje, senamiestis buvo Paminklu restauravimo ir projektavimo instituto (PRPI) monopolis, Kolūkių projektavimo institutas projektavo visus provincijos objektus, o Miestų statybos projektavimo institutui (MSPI) atitekdavo likusių bei „netipinių“ objektų projektavimas. Tai iš esmès skatino uždarus atskirų projektavimo institutų konkursus. Net viešuose, respublikiniuose konkursuose "neteisingo "instituto darbuotojo dalyvavimas tapdavo probleminis. Šią susiskaldymo padètį dar labiau sunkino ir bloga informacijos sklaida. Dažnai apie naują konkursą skelbdavo tik Architektų sajungos laiptinëje ar kokio projektavimo instituto koridoriuje kabantis skelbimas (Čaikauskas 1999). Jei tai būdavo atostogų metas, ar konkursas būdavo paskelbtas kitame mieste - apie ji sužinoti galedavo tik ribotas architektų skaičius.

Net ir tie negausūs architektūros konkursai, kurie ivyko, dažnai nebuvo etaloniniai. Neretas atvejis, kai objektas būdavo projektuojamas neatsižvelgiant ị jau ìvykusių konkursų rezultatus. Būtent toks buvo $1979 \mathrm{~m}$. organizuotas Respublikinių politinio švietimo namų (dabartinių Kongresų rūmų) Vilniuje konkursas. Pirma vieta ir teisè projektuoti neatiteko nei vienam konkurse dalyvavusiam autoriui. $1984 \mathrm{~m}$. be jokio konkurso užsakymas nukeliavo tiesiai į Miestų statybos projektavimo instituto II-ajji skyrių, kuris tuo metu buvo „netipinių“ pastatų projektavimo monopolistas Respublikoje. Iš pradžių darbas buvo pavestas archit. V. Čekanauskui (net nedalyvavusiam 1979 m. konkurse), tačiau siekiant kuo greičiau igyvendinti planą darbas perduotas greičiau dirbusiam jo kolegai E. Stasiuliui, kuris šį objektą ir realizavo (Mačiulis 2003). Panašiu scenarijumi baigèsi ir Ministrų Tarybos rūmų atsiradimo istorija. Taigi, kai valstybinis užsakymas būdavo konkretus ir aiškus - konkursai net nebūdavo skelbiami, o įvykusių rezultatai buvo ignoruojami atiduodant projektavimo teisę „patikrintam“ architektui. Tai rodo, kad planinès ekonomikos sąlygomis siekta tokio pat planingo rezultato ir architektūroje. Konkursai, kaip laisva konkurencija, prieštaravo šiam apibrež̌tumui.

\section{Sovietinių konkursų reikšmė architektų kūrybai}

Nepaisant visų to laikmečio konkursų sistemos trūkumų patys architektai, dalyvavę juose, pažymi didelę paties varžybų proceso reikšmę. Pavyzdžiui, monografijoje apie architektą G. J. Telksnį konkursinio projekto rengimas apibūdinamas kaip „papildomas kūrybinis krūvis - darbas po darbo. Ir nepaisant begalinio nuovargio, neišmiegotų naktų, kas tęsdavosi mènesiais $<\ldots>-$ tai buvo pats kūrybiškiausias, svaigiausias idejų ir svajonių metas" (Vaitys 2005). 
Būtent konkursai padèjo atsirasti gerai žinomam architektų Sauliaus Šarkino ir Leonido Merkino kūrybiniam duetui. Leonidas, nesužavètas valdiškų darbų prievolès, pasiūlè jaunesniam savo kolegai dalyvauti paskelbtame Jaunimo centro projekto Vilniuje, dabartinio Sereikiškiu parko vietoje, konkurse (1977 m.): „<...> bent jau niekas nevaržys fantazijos, nekiš po nosimi normu ar taisyklių <...> " (Vaitys 2007). Ju projektas konkurse buvo pripažintas antruoju ir tapo ilgo abieju konkursantų bendro kelio pradžia. Tarp ne vieno konkurso dalyvių ir prizininkų rastume ir architektų Algimanto ir Vytauto Nasvyčių pavardes (Petrulis 2007). Kaip jau buvo minèta, Revoliucijos muziejaus konkursas padéjo į profesines aukštumas iškilti ir vienam iškiliausių to meto architektų - Gediminui Baravykui (Buivydas 2000). Iki pat kūrybinio kelio pabaigos jis liko nuolatiniu konkursų dalyviu ir teike jiems didèlę reikšmę: „Šimtmetinè konkursų rengimo tradicija (L. StuokaGucevičius irgi laimėjo konkursus Vilniaus katedrai bei rotušei statyti) yra pačios architektūros prigimtyje. Ignoruodami šią tradiciją sulauksime bendros architektūros kultūros smukimo“" (Baravykas 1985).

Remdamiesi amžininkų atsiminimais galime ịvardinti pagrindinius architektų dalyvavimo sovietiniais metais konkursuose motyvus. Vienas iš jų - tai galimybė atitrūkti nuo kasdienybès, rutinos, sovietinių normų, primityvių technologiju ir ideologinès kontroles jungo (Vaitys 2007). Analizuodamas nuolatinių konkursų dalyvių S. Šarkino ir L. Merkino darbus, L. Vaitys taip pat pastebi profesinį tobulejjimą, sugebejjimą spręsti vis komplikuotesnių sąlygų diktuojamas užduotis, akivaizdų meistriškumo augimą ir ryžtą imtis pačiu sudètingiausių projektų: „, „..> išeiti tokią mokyklą sovietiniais laikais - didelè laimè <...>" (Vaitys 2007). Be galimybès brèžti sovietinèmis sąlygomis techniškai sudètingų, galima teigti, futuristinių objektų perspektyvas, konkursų dalyviai galejo laisviau imtis sudètingu užduočių, kurti naujos kokybès architektūrą. Vietiniai konkursai buvo ta varomoji jèga, kuri ribotu galimybiu sąlygomis padejjo vaduotis iš primityvios kasdienybès, siekti profesinių aukštumų, o retesni tarptautiniai konkursai leido pažvelgti ị save kitų, užsienio kolegų, akimis, pasitikrinti, ar iš tiesų nesivelkame pasaulio kūrejų uodegoje (Vaitys 2007). Nežiūrint visų sovietinių metų konkursų neproduktyvumo ir organizacinių trūkumų, galima daryti prielaidą, kad juose netiesiogiai buvo ruošiama dabartinès mūsų architektūros vizija ir ją igyvendinti galintys profesionalai.

\section{Išvados}

1. Sovietinių architektūros konkursų istorijoje atsispindi bendri epochos politiniai, visuomeniniai ir kūrybiniai ypatumai, giluminiai pokyčiai.

2. Sovietinio statybų masto neatitinkantis mažas organizuotų konkursų ir igyvendintų konkursinių projektų kiekis rodo, kad bendruoju atveju architektūros kokybe nebuvo prioritetinè. Išimtị sudarè tik politiniu ir ideologiniu požiūriu svarbūs objektai.

3. Didelis neigyvendintų konkursinių projektų kiekis - viena iš epochos ypatybių, kuri gali būti nulemta užsibrèžtų uždavinių nerealumu, blogai paruoštomis konkursų sąlygomis, prasta informacijos sklaida, neteisingu prioritetų išdèstymu.

4. Dalyvavimas konkursuose to meto architektams dažnai tapdavo galimybe nors laikinai atitrūkti nuo planinio projektavimo rutinos, normatyvinès ir ideologinès kontrolès, siekti profesinių aukštumų.

5. Konkursuose architektų igyti profesionalūs igūdžiai galèjo turèti netiesioginès teigiamos ịtakos bendram Lietuvos architektūros lygiui sovietiniu ir vèlesniu periodu.

\section{Literatūra}

Baravykas, G. 1985. 4 klausimai kūrèjams, Statyba ir architektūra 85/11: 18.

Buivydas, R. 2000. Architektas Gediminas Baravykas. Kūrybos pulsas. Vilnius: Archiforma, 28-35, 162-172, 194.

Buivydas, R. 2006. Neịvardytas, bet svarbus šiuolaikinès architektūros reiškinys, iš Architektūra: pozityvai ir negatyvai. Vilnius: Ex Arte, 48-63.

Cibas, A. 1964. Kaip atrodys ateityje Vilniaus miesto centras, Statyba ir architektūra 64/11: 18-25.

Čaikauskas, G. 1999. Konkursas - susibègimas ar susidūrimas, Archiforma 99/3: 95-96.

De Haan, H.; Haagsma, I. 1988. Architects in Competition: International Architectural Competitions of the Last 200 Years. New York: Thames \& Hudson, 9-10.

Devinduonis, R. 1998. Lietuvos ir Vakarų Europos regioninio ir miestų planavimo praktikos paralelès, Archiforma 98/1: 88-98.

Grunskis, T. 2007. Diktato architektūra (I). Lukiškių aikštė, Archiforma 07/1: 104.

Kančienè, J. 1996. Lietuvos architektų orientyrai tarpukaryje, Archiforma 96/1: 55-59.

Mačiulis, A. 2002. Lietuvos architektai. Vilnius: VDA leidykla, 77, 325.

Mačiulis, A. 2003. Portretas: Edmundas Pranciškus Stasiulis, Archiforma 03/1: 42-48. 
Mikučianis, V. 1997. Atsiminimai apie pokarinio Vilniaus konkursus, Archiforma 97/3: 74-80.

Nekrošius, L. 2007. Idejų paralelès: struktūralizmas, APS, $2007 \mathrm{~m}$.

Petrulis, V. 2007. Algimantas ir Vytautas Nasvyčiai: dvi asmenybès - viena architektūra, Archiforma 07/1: 50-59.

Riaubienè, E. 1999. Elena Nijolè Bučiūtè: architektūra - tai praktiné paskirtis ir meninè prigimtis, Archiforma 99/4: $42-48$.

Šešelgis, K. 1997. Vilniaus miesto Lukiškių aikštès formavimo projektai, Urbanistika ir architektūra 2(24): 32-53.

Vaitys, L. 2005. Gintautas Juozas Telksnys. Architektas. Vilnius: Artseria, 9.

Vaitys, L. 2007. Saulius Šarkinas. Architektas. Vilnius: Artseria, 11-13.

vasara: $30-37$.

Vyšniūnas, A. 1997. Mirę projektai: Autobusų stotis. Kaunas, Archiforma 97/3: 104-106.

Žickis, A. 1996. Architektūros projektų konkursai, Archiforma 96/2: 86-88.

\section{REVIEW OF ARCHITECTURAL COMPETITIONS OF THE SOVIET PERIOD IN LITHUANIA}

\section{Linartas}

Abstract. The paper deals with the main architectural competitions of the soviet period (1945-1990) in Lithuania. Referring to particular examples, efforts are made to identify development regularities of competitions at different stages of the soviet period, find out a relationship with the general architectural situation, discuss changes, to make a comparison with competitions of other historical epochs as well as to define their influence on the architecture and architects in Lithuania of that time. Peculiarities of competitions related to urbanistic projects, buildings and monuments representing both the early and "mature" socialism are introduced. Without attempting to list and examine in detail each creative competition of this era, efforts are made to perceive the essential principles of the very competition system of the soviet period. Problematicity related to "dead" projects, non-transparency of competitions and disregard of copyright typical to the Soviet times are discussed.

Keywords: architecture competition, Soviet period, dead projects, realisation, authorship.

\section{DARIUS LINARTAS}

Master, doctoral student (2007), Dept of Fundamentals and Theory of Architecture, Vilnius Gediminas Technical University (VGTU), Pylimo g. 26/Traku g. 1, LT-01132 Vilnius, Lithuania. E-mail:darlinas@gmail.com

Master of Architecture, VGTU, 1997. Membership: member of Lithuanian Union of Architects (1999). Publications: author of tens of publications in professional press. Projects: author or co-author of 21 realization of projects of architectural design. Teaching: architectural graphics (1997-2007), architectural design (2007) in VGTU. Research interests: theory and practice of architecture. 